\title{
Linking the forestry sector financial system with local government institutions
}

\author{
Frank H.J. van Schoubroeck', R.N. Sah and H. Sigdel ${ }^{2}$
}

The forestry sector is seriously underutilising its potential to contribute to national development objectives such as poverty alleviation, gender equity, economic development and environmental integrity. Since decades, realised revenues are but single-digit percentages of the value of the actual timber extraction. The Ministry of Forests and Soil Conservation can increase Terai forest revenues up to thirty times by establishing an efficient forestry governance system. The presently dominant productive forestry models are either extremely centralised (National Forest Management) or extremely decentralised (Community Forestry), and they represent a parallel governance structure in the country. Both management models are poorly linked to local government bodies. The latter could help rationalising forest management by providing necessary checks-and-balances in forest management.

This paper proposes to financially underpin on-going experiments with District Forestry Co-ordination Committees, Collaborative Forest Management, and other institutional reforms; in which local bodies, line agencies and civil society organisations jointly plan and implement forestry programmes. A decentralised financial system will allow local partners to co-operate for optimising productive and ecological functions of forests. Local bodies could allocate forest revenues for forestry-related programmes as well as general development. All major players can win: the local government can increase the local development budget, the Forestry Line Ministry can align with local bodies for sustainable forest management, Civil Society Organisations can influence planning and involve in implementation, and the Ministry of Finance can reduce central forestry budgets. The Ministry of Forests and Soil Conservation is the best positioned institution to coordinate the forestry financial system reform, which is a complicated but rewarding process.

\section{The need to review the forestry sector financial system}

Nepal's Forestry Sector needs better governance

Nepal's forcstry sector has a long tradition of contributing to the economy and the central treasury: However, over the last decades, forest-based economic growth slowed down (Hill, 1999, Gyawali, 2004). The sector's contribution to national development objectives like poverty alleviation, economic growth and environmental integrity are at best anecdotal (such as in Community Forestry) or a serious failure (such as in Terai and Chure forest management). The development of participatory institutional frameworks and acceptable forestry management models in the Terai is delayed (Kanel, 1994, Gyawali and Koponen, 2004). This paper is meant to shed some light on a possible sector-wide taxation and re-investment policy, keeping in mind the growing demand for transparency and regularity in society, the need to reconcile environmental and livelihood objectives, and the on-going national decentralisation policy. It starts with estimating possible benefits to the nation and a brief analysis of the present financial system, and then proposes a vision for a system to suit the needs of the forestry sector, for which relevant ministries should join hands.

An efficient forestry sector financial system will pay off

When discussing the financial system of the forestry sector, an indication of the potential volume of fund flow is useful. The following calculations are only

\footnotetext{
Dr. Frank van Schoubrocek is Senior Forestry Sector Advisor, Central Support Unit, BISI:P-ST, e-mail

frankivaschoubroeck@yahoo.com

- Hatrihar Sigdel and Ram Nandah Sah are Programme Managers of the Central and Regienal Support Linits, BISI:P-ST, respectively:
} 
indicative. For reason of simplicity; the estimated figures are based on timber production in the Terai alone. Potential production of fuel and NTFPs; and environmental effects as well as subsistence production in mid-hill and mountainous areas are not discussed here.

In 2003, the Ministry of Forests and Soil Conservation (MFSC) carried out four small-scale inventories in Rautahat, Bara and Parsa districts, showing that in all four plots of around 1500 ha each, the growing stock had declined (Rural Development Foundation, 2004; Innovative Development Associates, 2004). Decline ranged from 5 to $26 \%$ between 1994-95 and 2003; rather than an expected increase from annual incremental growth. Sustainable incremental growth of Terai forests is taken as three cubic meters (107 cft) per hectare per year (Department of Forests, 1995), of which around half is of timber quality, worth NRs 450 per cft. Based on these figures, Box 1 presents a rough calculation of economic potential and losses in Sabhaiya range post in Parsa ${ }^{3}$.

Based on measurements in Sabhaiya rangepost in 1995 and 2003, annually NRs 9.5 crore worth of umber is not accounted for. The potential sustainable production under proper management is estimated as NRs 3.3 crore per year. Sabhaiya rangepost is not exceptional; there are areas where degradation is worse, and there are areas where protection is better.

To indicate the monetary dimension of Terai-wide timber flows, as well as potential sustainable production from Government-managed forest, Table 1 provides the valuation of sustainable production of timber extrapolated over three districts, and over the nation. Potential sustainable production is only calculated for production forest; protection forest (which accounts for $71 \%$ of the Terai-Siwalik forest area) is not taken into account either for loss calculations or for potential production. The table shows that, on an annual basis, the annual economic turnover for timber sales of Terai production forests could be around NRs 13 arab (around $176 \mathrm{~m}$ L'SS). This figure is close to a figure of USS $160 \mathrm{~m}$ calculated earlier (Hill, 1999). The realised annual revenue for the same area is around NRs 27 crore. If the revenue values about half of the turnover (which is a realistic estimate), then the realised annual revenue is less than $5 \%$ of its sustainable potential, and even less of the estimated actual extraction.

The figures indicate that an institutional framework to efficiently manage Terai forests can improve both forest revenues and protection.

\section{Box 1 : Financial analysis of the Sabhaiya range post forest in Parsa}

Sabhaiya range post takes care of a production forest situated just south of the Parsa Wildlife highway. The forest area is 1,383 hectar southern belt, ten kilometres west of the Patlaiya-Birgunj Management Plan, the growing stock 1,38 . During the preparation of the 1995 Operational Forest stock should have increased $4,512 \mathrm{cft}$ per hectare; ated at 6,111 cubic feet per hectare. In 2003, the At a market standing value of NRs 450 per cft for ti hectare per year) to up to 6,964 cft per hectare.

Expected value of Sabhaiya forest was timber, and a ratio of 50-50\% timber-fuel per hectare, the the difference of NRs 5.5 larvesting would 13.8 lakh per hectare in 1995; NRs 10.2 lakh in 2003. crore, which means a 5.5 lakh per hectare, the been NRs 15.7 lakh per hectare. Should we consider average sale proceedilue reduction NR; the stock reduction between 1995 and 2003 is NRs 76.3 was NRs 9 lakh, so less than $1 \% 3$ for an are crore (equivalent to US\$1.3 m) per year. The realised loss is split between the reduction of the expected equivalent to Sabhaiya rangepost in Parsa district sustainable harvesting level (NRtion in growing value should all timber have been harvested. This has the potential to sustainably 3.3 crore ann stock (NRs 6.2 crore annually) and the potential structure is operational. Add produce timnually). Thus, on an annual basis, Sabliaiya rangepost environmental effects. Additional benefitser worth NRs 3.3 crore - if an effective management environmental effects such as a stable wate would come from fuelwood, herbs and leaves, and water table in nearby agriculture areas.

\footnotetext{
In 20103, ll'SS was equivalent to around 75 NRs. 1 lakh $=100,000 ; 1$ crore $=10,000,000 ; 1$ arab $=1,000,000,000$.
} 
Table 1. Financial valuation of loss and potential timber and fuelwood production

\begin{tabular}{|c|c|c|c|c|c|c|}
\hline Command area & $\begin{array}{l}\text { Production } \\
\text { Forest Area }\end{array}$ & $\begin{array}{l}\text { Timber } \\
\text { value } \\
\text { growing } \\
\text { stock } \\
1994-95 \\
\text { (in lakhs } \\
\text { NRs) } \\
\end{array}$ & $\begin{array}{l}\text { Timber } \\
\text { value } \\
\text { growing } \\
\text { stock } 2003 \\
\text { (in lakhs } \\
\text { NRs) } \\
\end{array}$ & $\begin{array}{c}\text { Annual } \\
\text { reduction } \\
\text { in timber } \\
\text { value of } \\
\text { growing } \\
\text { stock } \\
\text { (in lakhs } \\
\text { NRs) } \\
\end{array}$ & $\begin{array}{c}\text { Annual } \\
\text { potential } \\
\text { sustainable } \\
\text { timber } \\
\text { production } \\
\text { (in lakhs } \\
\text { NRs) }\end{array}$ & $\begin{array}{c}\text { Realised } \\
\text { average } \\
\text { annual } \\
\text { revenue in } \\
1995-2003 \\
\text { (in lakhs } \\
\text { NRs) } \\
\end{array}$ \\
\hline Sabhaiya rangepost & 1,383 & 19,016 & 14,1141 & 954 & .3 .32 & 9 \\
\hline Maduban rangepost & 1,815 & 21,828 & $16,56.3$ & 1,093 & 4.35 & 12 \\
\hline Tamangadi rangepost & 1,935 & 17,789 & $16,9.37$ & 571 & 464 & 12 \\
\hline Rangpur rangepost & 1,450 & 16,460 & $13,2.32$ & 751 & 348 & 8 \\
\hline Average per hecrare & & 11.41 & 9.23 & 0.27 & 0.24 & 0.01 \\
\hline Parsa & 13,606 & 125,583 & 125,583 & 3,674 & 3,263 & 84 \\
\hline Bara & 30,607 & 349,226 & 282,503 & 8,264 & 7,340 & 196 \\
\hline Rautabat & 15,870 & 181,077 & 146,480 & 4,285 & 3,806 & 88 \\
\hline Central region & 79,283 & 904,619 & 731,782 & 2,1406 & 19,014 & 678 \\
\hline Nation & 550,000 & $6,275,500$ & $5,076,500$ & 148,500 & 131,905 & 2,721 \\
\hline
\end{tabular}

Source: Based on OFMP production figures, 2003 prices and Department of Forests sale figures for 1995-2003. Figures in italics are extrapolated and should be taken as indicative only.

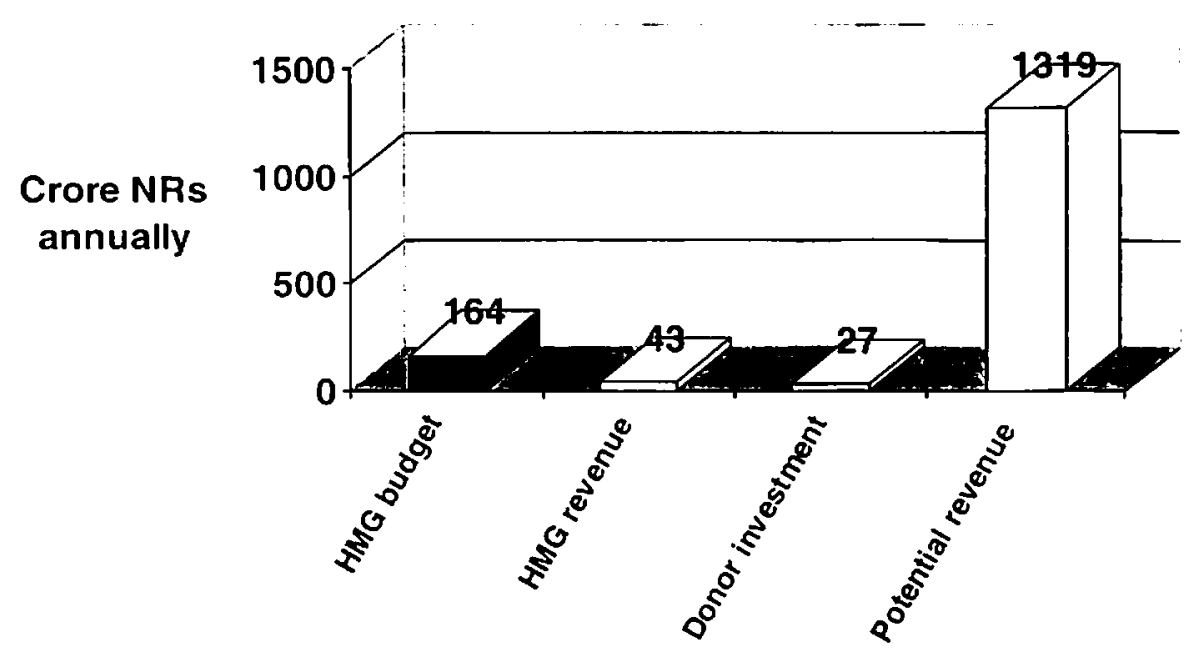

Figure 1. Monetary volumes of the annual HMG-forestry sector budget and revenue, donor investment, and potential sustainable timber revenue from Terai production forests (based on Sigdel, 2003).

Figure 1 gives a graphic representation of some indicative figures in the forestry sector, derived from Sigdel, 2003 (who analysed figures for 1997-2003), DoF, 2003 and Table 1. For the government, the forestry sector costs NRs 164 crore (regular plus development budget), while revenues are around NRs 43 crore (2002-2003 data). The annual contribution to the GDP by timber production in the Terai could value up to NRs 13 arab (1319 crore), around $15 \%$ of the national budget. In 1997-2003 donors invested around NRs 27 crore annually through the national budgeting system. Probably donors a few times that amount through direct funding, mostly in the Community Forestry programme and Wildlife
Conservation. Earlicr efforts to support productive management in the Terai tailed (Gyawali and Koponen, 2004); since a few years new efforts to utilise Terai forests are underway.

\section{The forestry sector financial system in brief}

The present investment system in the forestry sector

For an understanding of the present financial system of the forestry sector, we should concentrate on investment cycles directly linked to investments for sustainable forest-based economic development. 
Figure 2 (derived from Rijn, 2002) schematically shows the dominant financial cycles in the forestry sector. Major investment cycles include a national forest management cycle and a community forest investment cycle:

- For government-managed forests, the Ministry of Finance $(\mathrm{MoF})$ allocates funds through the Department of Forests (DoF); mainly for protection and collection of dead and fallen trees. $90 \%$ of the revenues are submitted to the central treasury; $10 \%$ to the District Development Committee (DDC), with little expenditure on forestry activities.

- Revenues from Community Forests go to the Forest User Committee which decides on investments in forest management and other expenditures. Since 2002, a legal battle is going on between MFSC and Community Forest User Group (CFUG) associations about a $10-40 \%$ taxation on products sold outside the CFUG; revenues are to be submitted to the DF(); i.e., to
the central treasury:

There are a few problems with the present financial government managed on investment levels in Ministry of Finance, with litele taken by the investment-revenue ratios little feed-back about 2002-2003, the Ministry of Finance, in Bara in budget of 50 lakh for the finance scrapped a fallen trees, missing an opportunity to generate revenue of NRs 3 crote over the same Fiscal Y'car. Secondly; C.FL G is produce benefits and revenues, as managed by the user committec. In rural Nepal reality; local elite casily dominates re-iniestment decision making, and is not held sufficiently accountable for long-term productivity and objectives such as poverty reduction and gender equity. Third, local bodies lack formal rights over both government-managed and community forests that represent a major resource in their area. In fact, the Forestry Sector has set up a complete parallel governance structurc. For example, Forest User Groups (due to their access to resources) often finance local development activitics, which arc in fact functions of local government bodies. However, CFUGs structurally exclude non-group members.

Different taxation and marketing mechanisms for timber of different origin

At this moment, the forestry sector lacks a coherent taxation system. The taxation of timber from national forest, community forest, collaborative forest, and others, is inconsistent. A quick analysis of the taxation on timber harvested from different management modalities is shown in Table 2 . In all cases the sum of the stumpage value (royalty) plus handling costs make the minimum sale price. At auctioning, the price may get higher, rcsulting in margins. An exception is the internal sale of timber within Community Forest User Groups (CFUGs) with internal price fixing.

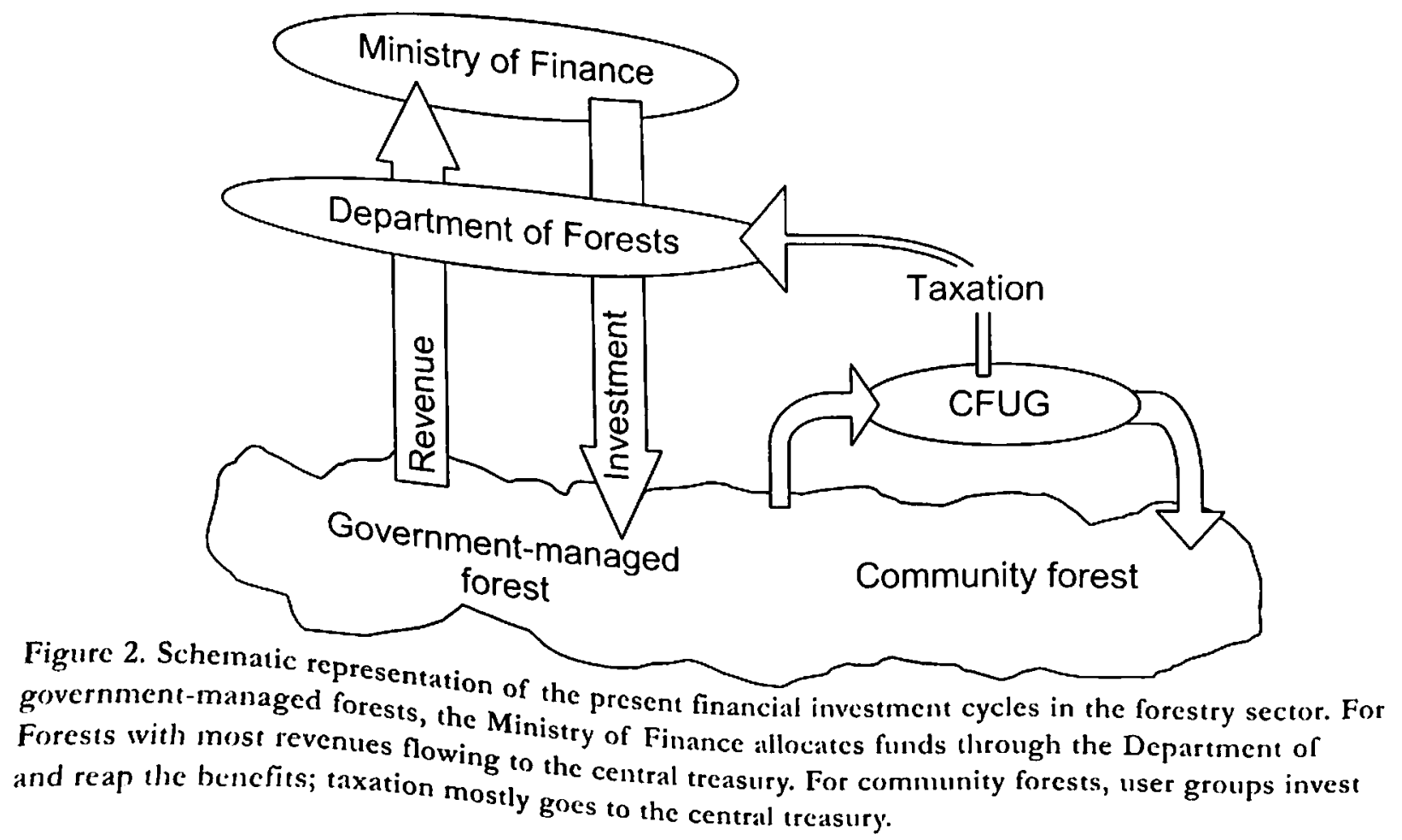


Table 2. Timber lots originating from different forest management modalities have vastly different tax bases, resulting in an irregular timber price formation.

\begin{tabular}{|c|c|c|}
\hline Forest modality & $\begin{array}{l}\text { Handling institution and sales } \\
\text { procedure }\end{array}$ & Taxation \\
\hline $\begin{array}{l}\text { Government-managed } \\
\text { forest }\end{array}$ & DFO harvesting and auctioning & $\begin{array}{l}10 \% \text { of sales value minus handling costs goes to } \\
\text { the DDC. }\end{array}$ \\
\hline $\begin{array}{l}\text { Government-managed } \\
\text { forest }\end{array}$ & TCN harvesting and auctioning & $\begin{array}{l}\text { Handling costs plus margins go to the TCN; the } \\
\text { royalty to the DFO; who pays } 10 \% \text { to the DDC } \\
\text { and } 90 \% \text { to the central treasury }\end{array}$ \\
\hline $\begin{array}{l}\text { Government-managed } \\
\text { forest }\end{array}$ & $\begin{array}{l}\text { District Forest Products Supply Board } \\
\text { (DFPSB) that fixes the price for sales to } \\
\text { the public }\end{array}$ & $\begin{array}{l}\text { Handling costs plus margins go to the DFPSB; } \\
\text { the royalty to the DFO (only } 10 \% \text { in case of } \\
\text { disaster relief); who pays } 10 \% \text { to the DDC and } \\
9(1 \% \text { to the central treasury. }\end{array}$ \\
\hline $\begin{array}{l}\text { Community forestry } \\
\text { (internal sale) }\end{array}$ & $\begin{array}{l}\text { Forest User Group (sale as per internally } \\
\text { defined procedure) }\end{array}$ & No taxation imposed \\
\hline $\begin{array}{l}\text { Community Forestry } \\
\text { (cxternal sale) }\end{array}$ & $\begin{array}{l}\text { Forest User Group (sale as per internally } \\
\text { defined procedure; minimum price is } \\
\text { royalty + handling costs) }\end{array}$ & $\begin{array}{l}\text { Tasation } 40 \% \text { of sale price minus handling costs } \\
\text { (for sal and khair); the } D F() \text { pays } 10 \% \text { to the } \\
\text { DDC and } 90 \% \text { to the central treasury }\end{array}$ \\
\hline $\begin{array}{l}\text { Collaborative Forest } \\
\text { Management }\end{array}$ & $\begin{array}{l}\text { Collaborative Management Sub- } \\
\text { Committee }\end{array}$ & $\begin{array}{l}\text { Handling costs }+ \text { (rovaity }+ \text { profit) of which } 25 \\
" 1 \text { of sales price to various district stakeholders, } \\
75 \% \text { to national government }\end{array}$ \\
\hline Driftwood & DF( ) harvesting and auctioning & $\begin{array}{l}\text { Of sales price minus handling costs, } 50 \% / \mathrm{mocs} \text { to } \\
\text { the DDC and } 50 \mathrm{~m} / \mathrm{to} \text { the central treasury }\end{array}$ \\
\hline
\end{tabular}

The table shows that the price build-up of timber varies between different management modalities, not only in level of taxation, but also in principle of taxation (royalty is an absolute taxation; $40 \%$ is a relative taxation). The result is a blurred discussion on forest management modalities to be applied, where tax levels rather than institutional arrangements are brought up as major arguments (see for example Forest Action, 2003), hampering proper development of Terai forestry modalitics (Bampton, pers. comm.). The responsibility for marketing timber from government-managed forests lays with the DoF and the Timber Corporation of Nepal; which are accountable to MFSC, with little transparency, and a consequent mistrust from the general public (Mitchell et al., 2001). Besides, most timber comes on the market through CFUGs or illegally, with a non-transparent price formation (e.g., Baral, 2001, Chettry et al., in prep. Gyawali, 2004). It is therefore no surprise that the timber market shows considerable inconsistency, and the price one pays depends on relations rather than the market decides.

The need for a sector-wide financial system that fosters trust

We can conclude that the present revenue and investment system is not fostering confidence among major stakeholders in the sector. The institutions responsible for handling of forest resources (CFUGs, DoF) lack transparency, particularly in areas where forests represent vast economic resources, both in government managed and in community forestry. Groups that manage forests and generate revenues are willing to pay tax if it would be re-invested in forestry, or if it would be spent on development activities by local bodies. It is thus time to design a system that fosters trust; between central and local government, elite and non-elite, men and women, CFUG-members and non-members, and resourcerich and resource-poor areas; as to increase efficiency of forestry sector governance.

\section{Decentralising the financial system for better forestry governance}

\section{A financial system linked to local government bodies}

The presented figures show that there is a need for a taxation and reinvestment system that supports economic devclopment and sustainable forest management; both for socio-economic and for macro-economic purposes. Some characteristics of the system would be:

- The forestry taxation system should allow for monitoring of marketing by credible institutions such as local governments or treasury offices with a leyal enforcement mandate.

- Tax payers should have reasonable control over taxation moncy expenditures.

- Local government bodies take care of redistribution over areas and sectors, while the 
national government takes care of re-distribution of revenues over regions.

- Productive activities should be directly paid from the revenues of the particular forest.

- Wider, forestry-related activities (e.g., in renewable energy programmes) should be paid from forest revenues.

- Marketed timber from either forestry modality should be taxed similarly:

- Decision-making bodies should apply' tools such as equity and gender budgeting to ensure forest sector accountability to national policy commitments.

Decentralising the financial system fosters local responsibility

Over the last decade, the political and legislative environment is fostering local involvement in development activities, particularly by involving locally elected bodies (Ministry of Law and justice, 1999). The forestry sector is experimenting with Forestry Co-ordination Committees (FCCs) at local and district level, in which Line Ministry representatives, local bodies and civil socicty take part in planning and monitoring the forestry programme (Schoubrocck and Karna, 2003, Bampton, 2003). Village, District and Regional FCCs, or other groups such as Community or Collaborative Forest Management-groups, can play a key role in taxation and allocation of re-investments. Figure 3 conceptualises a financial system that address the concerns raised in previous Section. A central element is the idea of local forestry funds such as the District Forestry Development Fund, at the disposal of the District Forestry Co-ordination Committec (DFCC) (e.g., Sah, 2002, Rijn, 2002).

A few opportunities of a devolved financial system that come to mind are:

- Local Government Bodies can monitor financial management of Community and Collaborative Forest Management, fostering transparency and regularity.

- Revenues from participatory forestry models (community and leasehold forestry, collaborative forest management, bufferzone and park management) will be allocated to local Forestry

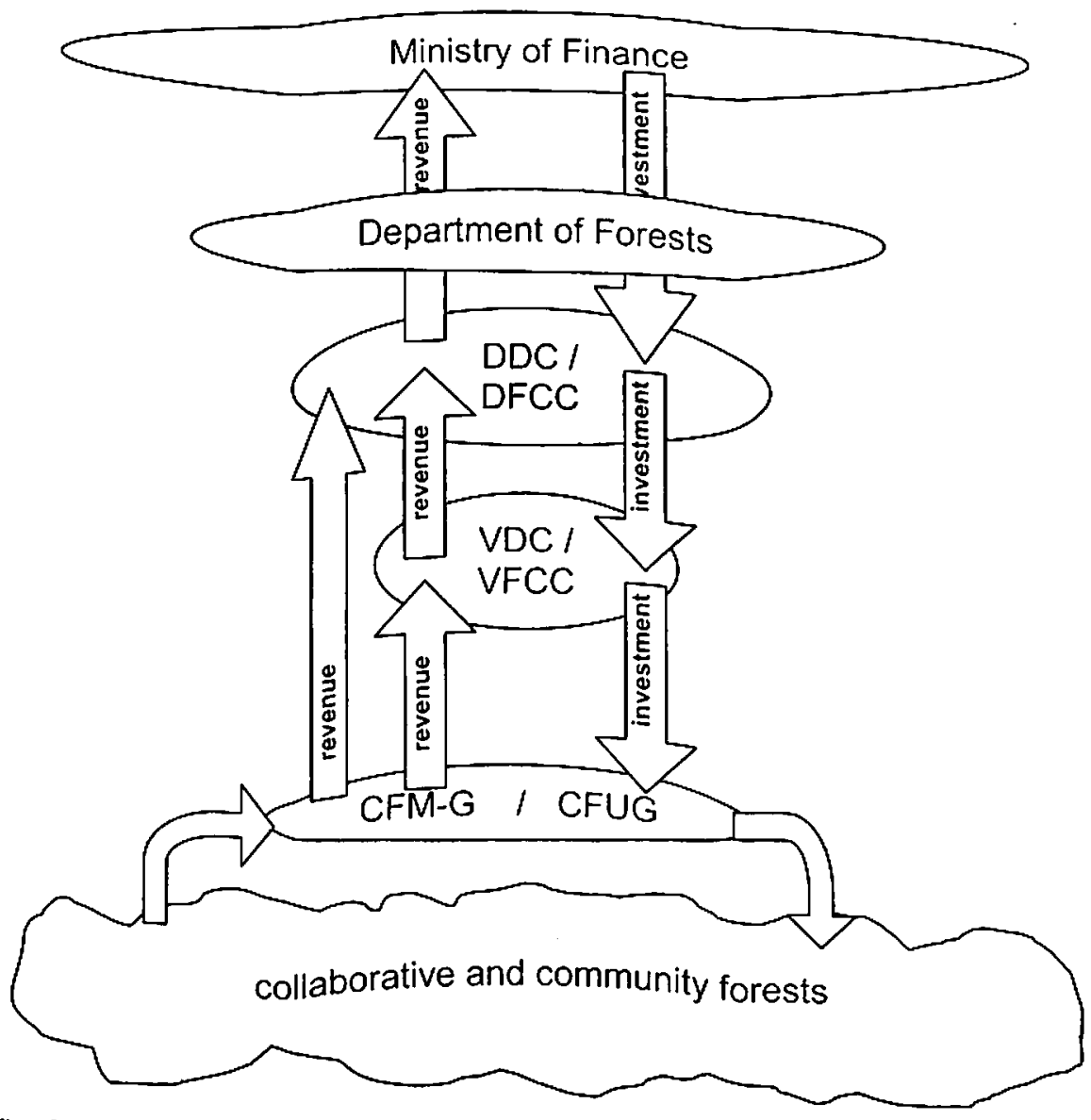

Figure 3. Sketch of a financial system with taxation and planning links to village and district government bodies. The system allows revenues to be locally invested in forestry activities; with taxing links to higher governance levels for higher-level services and rc-distribution of resources. 
Development Funds for the implementation of forestry sector plans, and to development in general; as per locally defined sharing quotas.

- Local forestry development funds allow for locally planned and managed forestry programmes through FCCs.

- In productive areas (such as in the Terai), part of the forest revenues will replace national financing of development activities, and part of the revenue will go to the central trcasury for national development.

- Donors can support local institution building by targeted capacity building and funding of activitics through local management mechanisms; to be phased over to local funding.

For cxample, in a particular hill district, the $40 \%$ taxation of Community Forestry will be submitted in the District Forestry Development Fund; the DFCCs then choose to support the DFO and NGOs to spread of community forestry all over the district, or utilise the resources for a gender and equity programme. Or, the CFM-Group submits its revenues to the District Forestry Development Fund, who disburses funds for a Private Forestry Programme in distant Village Development Committees (VDCs) through the Village Forestry Development Fund. Through such mechanisms, the forestry sector can institutionalise social equity and reduce its dependence on foreign financing.

\section{Local Forestry Co-ordination Committees monitor and plan forestry activities}

Prerequisite for a successful taxation and reinvestment system is a transparent collection of the revenues and expenditure planning. For the formation of decentralised forestry programme planning, MFSC and local bodies are establishing FCCs at various levels. They typically consist of representation of the 'ocal bodies, the line departments, and of civil society and private sector ${ }^{4}$. These committees will monitor forest revenue generation and distribution, and develop local forestry sector development plans. FCCs might be linked to a particular patch of forest (e.g., in community forestry and in collaborative forest management), or might be linked to a particular local government body (c.g., in case of DFCCs and VFCCs

Table 3. Major Forestry Co-ordination Committees, their constituency and forestry development fund.

\begin{tabular}{|c|c|c|c|}
\hline $\begin{array}{l}\text { Forestry Co-ordination } \\
\text { Committee (FCC) }\end{array}$ & $\begin{array}{c}\text { Closest general } \\
\text { government body } \\
\text { (forestry structure may } \\
\text { be inconsistent with } \\
\text { existing delineation) }\end{array}$ & Constituency & $\begin{array}{l}\text { Forestry Development Fund } \\
\text { (FDF) and planning }\end{array}$ \\
\hline $\begin{array}{l}\text { Forestry Sector Co- } \\
\text { ordination Commitree }\end{array}$ & $\mathrm{HMG} / \mathrm{MFSC}$ & National population & $\begin{array}{l}\text { Central treasury / Donor funds } \\
\text { not consolidated; to implement } \\
\text { the Masrer Plan for the forestry } \\
\text { sector and five-lear plans }\end{array}$ \\
\hline $\begin{array}{l}\text { Regional Forestry Co- } \\
\text { ordination Committee }\end{array}$ & $\begin{array}{l}\text { Regional Administrative } \\
\text { Offices / Regional } \\
\text { Directorate of I:orests }\end{array}$ & Regional population & $\begin{array}{l}\text { Red Book / Donor funds not } \\
\text { consolidated }\end{array}$ \\
\hline $\begin{array}{l}\text { District Forestry Co- } \\
\text { ordination Committee }\end{array}$ & $\begin{array}{l}\text { District Development } \\
\text { Committee }\end{array}$ & District population & $\begin{array}{l}\text { District Forestry Sector } \\
\text { Development fund; to } \\
\text { implement the District } \\
\text { Forestry Sector Plan }\end{array}$ \\
\hline $\begin{array}{l}\text { Collaborative Forest } \\
\text { Managenent Committee }\end{array}$ & $\begin{array}{l}\text { Ilaki, or a group of } \\
\text { VDCs }\end{array}$ & $\begin{array}{l}\text { Collaborative Forcst } \\
\text { Management Group }\end{array}$ & $\begin{array}{l}\text { Collaborative Forestry } \\
\text { Development fund; to } \\
\text { implement the CFM-scheme }\end{array}$ \\
\hline $\begin{array}{l}\text { Village Forestry Co- } \\
\text { ordination Committee } \\
\text { (not yet operational) }\end{array}$ & $\begin{array}{l}\text { Village Development } \\
\text { Committec }\end{array}$ & VDC population & $\begin{array}{l}\text { Village Forestry Development } \\
\text { fund }\end{array}$ \\
\hline Bufferzone Committee & $\begin{array}{l}\text { Ilaka, group of VDCs or } \\
\text { wards }\end{array}$ & Bufferzone population & $\begin{array}{l}\text { Bufferzone fund; to implement } \\
\text { the Bufferzone Scheme }\end{array}$ \\
\hline $\begin{array}{c}\text { Community Forest Users } \\
\text { Committee }\end{array}$ & $\begin{array}{l}\text { tole, ward or part of } \\
\text { VDC }\end{array}$ & $\begin{array}{l}\text { Community Forestry } \\
\text { User Group }\end{array}$ & $\begin{array}{l}\text { Forest User Group Fund; to } \\
\text { implement the Operational } \\
\text { Plan }\end{array}$ \\
\hline
\end{tabular}

\footnotetext{
"An exception is community forest user groups that consist of forest users with no formal represenration of lecal government or line ministry:
} 
linked to DDCs and VDCs). Table 3 presents a list of such committees. A financial framework that allows the various FCCs to retain authority over part of the local revenues will increase their capability in managing local forest resources.

\section{Changing institutional roles}

The financial system of the forestry sector is to underpin a more general forestry governance system (FACD, 2004). Table 4 present a rough task division in the forestry sector, where line ministries, local bodies and NGOs will take up particular tasks. The exact way in which different stakeholders will link their implementation capacity (proceeding of sales, forest management, support for income generation, gender and equity functions) is yet to be developed. At present, the DFO is the main implementer of planned forestry activities. Once local forestry development funds get established, the FCCs develop programme support units for administration of the Forestry Development Funds. Such units are already being experimented with in some sector support programmes.

\section{Discussion}

The financial reform strategy is an essential element of larger forestry sector institutional reform at national, district and local level. At the national level, decentralisation policy is proposed therugh the l oucal Self-Governance Act (Ministry of I aw; 1999) with

Table 4. Present and possible future role of various institutions related to the forestry sector.

\begin{tabular}{|c|c|c|}
\hline Institution & $\begin{array}{l}\text { Present role } \\
\text { in forestry sector }\end{array}$ & $\begin{array}{l}\text { Possible future role } \\
\text { in forestry sector }\end{array}$ \\
\hline Ministry of Finance & $\begin{array}{l}\text { allocation of funds for } \\
\text { forestry activities } \\
\text { through central } \\
\text { government channel }\end{array}$ & $\begin{array}{l}\text { - providing financial framework } \\
\text { taxation and redistribution of revenucs over sectors } \\
\text { and regions }\end{array}$ \\
\hline MFSC / DoF & $\begin{array}{l}\text { - planning of forestry } \\
\text { investments } \\
\text { - implementing forestry } \\
\text { programmes }\end{array}$ & $\begin{array}{l}\text { providing forestry policy framework, including } \\
\text { forestry governance structure } \\
\text { - central co-ordination tasks of forestry sector } \\
\text { - linking to international developments, treaties, etc. }\end{array}$ \\
\hline $\begin{array}{l}\text { District Development } \\
\text { Committee }\end{array}$ & - & $\begin{array}{l}\text { - providing general policy framework } \\
\text { - investment forestry revenues in general clcrelopment } \\
\text { - pay rax to central tieasury }\end{array}$ \\
\hline $\begin{array}{l}\text { District Forestry Co- } \\
\text { ordination Conmmittee }\end{array}$ & . - & $\begin{array}{l}\text { - planning forestry programmo } \\
\text { - mke forestry programme }\end{array}$ \\
\hline District Treasury ()ffice & - channelling of funds & - audit service to forestery development fund \\
\hline $\begin{array}{l}\text { District Forest Office / } \\
\text { other line agencies (soil, } \\
\text { parks, women\& social } \\
\text { welfare, etc.) } \\
\text { District Sim }\end{array}$ & $\begin{array}{l}\text { - implement development } \\
\text { programmes }\end{array}$ & $\begin{array}{l}\text { - provide legal framework } \\
\text { - law enforcement } \\
\text { - co-ordinate with national Ministries }\end{array}$ \\
\hline District Support Unit & - - & $\begin{array}{l}\text { - co-ordinate with all implementing agencies } \\
\text { - managc district forestry development fund } \\
\text { - contracting service providers for jobs in planning } \\
\text { - support DFCC-functions (m\&e, planning, etc.) }\end{array}$ \\
\hline NGOs \& civil society & " advocacy 'on the street' & $\begin{array}{l}\text { - advocacy in (C,R,D,V) FCCs } \\
\text { - implementing specific programmes (training, } \\
\text { awareness, social mobilisation, gender \& equity) } \\
\text { - prepare operational plans }\end{array}$ \\
\hline Village Development & $\begin{array}{l}\text { contracting operational } \\
\text { activities }\end{array}$ & - contracting operational activitics \\
\hline Village Foresiry Co- & $\because$ & $\begin{array}{l}\text { - utilise forest taxation for development activitics } \\
\text { - pay tax to DDC for gencral community derelopment } \\
\text { and DFCC-planned support to forestry activities }\end{array}$ \\
\hline ordination Committec & manom $f$ & $\begin{array}{l}\text { - planning forestry programme for local needs, } \\
\text { inclucling povern reduction and gender balance } \\
\text { - mee }\left(\mathrm{F}^{*} \text { and } \mathrm{C}\right] \mathrm{M} \text {, including financial monitoring }\end{array}$ \\
\hline $\begin{array}{l}\text { CFM) } \\
\text { Corest uset Grou }\end{array}$ & $\begin{array}{l}\text { - manage forest } \\
\text { invest revenues in } \\
\text { general development }\end{array}$ & $\begin{array}{l}\text { - manage forests } \\
\text { pay tax to VDC for general community development } \\
\text { and VFCC-planned support to forcstry activities }\end{array}$ \\
\hline
\end{tabular}


vast consequences for district and local forestry programming. At the sector level, MFSC is developing an institutional reform agenda. Major moves include the introduction of taxation of forest produce, the development of linkages between local government, civil society and line agencies for planning and monitoring (MFSC, in prep.a); develop implementation linkages between line agencies and civil society (MFSC, in prep. b; NARMSAP NGOstudy taskforce, 2003); and development of collaborative approaches for forest management (MFSC, 2003). At the heart of the financial reform strategy are the Forestry Development Funds financing Forestry sector plans and sustaining the new institutional set-up. This will lead to more pronounced addressing of local needs and a wide feeling of ownership over the forestry programme.

This article argues that financial and institutional reform is the sensible thing to do. That in itself does not mean it will indeed happen. Links between existing (centralised, or donor-funded) systems to possible (locally managed, locally' funded) sy'stems are yet to be developed. One can imagine that first central and donor funding supports locally planned programmes, with a phasing over strategy to locally managed funds. The approach will need experimentation. The process for reform is complicated and can only succeed if relevant actors such as forest users, local bodies and relevant Ministries support, push and co-ordinate. Informal discussion with officials of the Ministry of Finance and the Ministry of Local Development suggest that they regard MFSC as the best positioned to coordinate the reform process. MFSC thus could initiate an inter-Ministry financial reform task force that hires an experienced service provider for wide consultation, drafting of legislation, piloting with help of donor-supported programmes, for final legislation and nation-wide introduction.

We argue that the forestry sector is in dear need of a governance system with wide public involvement and financial underpinning. After all, every day the nation is loosing around NRs 4 crore in missed revenucs and reduced timber stock. Improved sector governance will create room for local people to save forest and unblock its potential as a vast contributor to national development objectives. By developing an inclusive institutional framework, MFSC has a unique chance to show that it takes its responsibility serving the nation and the people. The task ahead is complicated but rewarding.

\section{Acknowledgements}

This article is based on a discussion paper prepared on request of Dr. D.P. Parajuli. Mr. L.P. Dakal collected internal MFSC-comments. We thank Mr K.M. Pradhan (Rural Development Foundation) for exposing the concept to colleagues in the Ministry of Local Development and the Ministry of Finance. This article is based on extensive discussion in the DFCCs of particularly Mahottari, Parsa, Bara and Rautahat, and of the Central RFCC; including the respective DDC-Chairpersons. Dr. A.N. Das and Mrs. K. Danielsen provided useful comments on earlier versions.

\section{References}

Bampton, J., 2003. District Forest Coordination Committees (DFCCs) - A Vision for Forest Sector Coordination and Transparency based on Experiences to date in the LFP-Terai Districts in the Lumbini Zone: Nawalparasi, Rupandehi \& Kapilbastu, and Interaction with BISEP-ST.

Baral, Jagadish C., 2002. Unintended outcomes of community forestry intervention in Ncpal: some implications. In: Banko Jankari, Vol. 12, No 1, May' 2002.

Chettry, Birkha, Paul Francis, Madhu Gurung, Vegard Iversen, Ghanendra Kafle, Adam Pain and Janet Seeley, in prep. Challenges to incrcasing the opportunities for the poor to access benefits of common pool resources - The case of Community Forestry in the Terai of Nepal. In: Stocking, Michel, Hilde Helleman and Roger White, in prep. Renewable Natural Resource Management for Mountain Communities. ICIMOD/DFID, Kathmandu, Nepal.

Department of Forests, 1995. (Operational Forest Management Plan for Parsa district.

Deparement of Forests, 2003. Hamro Ban 2059-2060. Babar Mahal, Kathmandu.

Forcign Aid Co-ordination Division, MFSC, 2004. Foreign Aid Policy for the forestry sector. MFSC, Singha Durbar, Kathmandu.

Forest Action, 2003. Hamro Ban Sampada. Volume 1(3), 2060.

Gyawali, Dipak and Juhani Koponen, 2004. Missionary zeal on retreat. Or, the strange ephemerality of the Bara Forest Management Plan. In: Sharma, Sudihindra, Juhani Koponen, Dipak Gỵawali and Ajaya Dixit, 2004. Aid under 
stress. Water, forests and Finnish Support in Nepal. Published by Himal Books for Institute of Development Studies, University of Helsinki, and Interdisciplinary Analysts, Kathmandu, 258 pp.

Gyawali, Dipak, 2004. Governance, corruption and foreign aid. In: Sharma, Sudihindra, Juhani Koponen, Dipak Gyawali and Ajaya Dixit, 2004. Aid under stress. Water, forests and Finnish Support in Nepal. Published by Himal Books for Institute of Development Studies, University of Helsinki, and Interdisciplinary Analysts, Kathmandu, 258 pp.

Innovative Development Associates (IDEA), 2003. Study report on socio-economic opportunities of Terai forest management. (I) Pilot Site I Sahajnath (Madhuvan). (II) Pilot Site II Tamagadi, Bara. Kathmandu, Nepal.

Kanel, K.R., 1994. Market opportunities and constraints. Forest Management and Utilisation Development Project, Kathmandu, Nepal. Working Paper No: 13.

Kanel, K.R., 2000. Management of the Terai, Inner Terai and Chure Forest Resource: A Reflection and Perspective. (Draft) In: Management of the Forests in Terai and Inner Tcrai Nepal. Collection of papers presented at the National Workshop organised by Nepal Foresters' Association, February 11-12, 2000, Kathmandu.

Ministry of Law and Justice, 1999. Local SelfGovernance Act 2055 (1999). Law Books Management Board, His Majesty's Government, Kathmandu, Nepal.

Ministry of Forests and Soil conservation, 2003. Guideline for Collaborative Forest Management,
2060. (In Nepali)
Ministry of Forests and Soil Conservation, in prep. a. District Forest Coordination Committee Establishment and (Operation Guidelines. (In Nepali)

Ministry of Forests and Soil Conservation, in prep. b. Strategy for partnership between government and civil society in the forestry sector.

Mitchell, Andrew, Puskar Bajracharya and N.R. Baral, 2001. Nepal fuel wood and timber marketing study. Final report. Ministry of Forests and Soil Conservation and World Bank.

NARMSAP NGO-study Taskforce, 2003. Partnering with civil society Organisations in NARMSAP supported areas. NARMSAP, Babar Mahal, April 2003.

Rijn, H. van, 2002. BISEP-ST Funding Arangements. Internal working document.

Rural Development Foundation, 2004. Socioeconomic opportunities of Terai forest management. Final reports of Sabhaiya pilot site (Parsa) and Rangapur Pilot Site (Rautahat). Babar Mahal, Kathmandu, Nepal.

Sah, R.N., 2002. District Forestry Sector Investment Fund (DFSIF). Internal working paper, MFSC / BISEP-ST, Babar Mahal, Kathmandu, Nepal, 5 Pp.

Schoubroeck, Frank van, and A.L. Karna, 2003. Initiating co-ordination platforms for Forest Management in the Terai. Banko Jankari, Volume 13 , no 2.

Sigdel, H., 2003. Donor contribution in Forestry Development. Masik Jiwan, year 4, number 14. (In Nepali) 